University of Nebraska - Lincoln

DigitalCommons@University of Nebraska - Lincoln

USDA Forest Service / UNL Faculty Publications U.S. Department of Agriculture: Forest Service -National Agroforestry Center

May 2008

\title{
Transient physiological responses of planting frozen root plugs of Douglas-fir seedlings
}

\author{
M. Anisul Islam \\ Purdue University, West Lafayette, IN \\ Douglass F. James \\ Purdue University, West Lafayette, IN \\ Kent G. Apostol \\ Purdue University, West Lafayette, IN
}

A. Kasten Dumroese

US Department of Agriculture Forest Service

Follow this and additional works at: https://digitalcommons.unl.edu/usdafsfacpub

Part of the Forest Sciences Commons

Islam, M. Anisul; James, Douglass F.; Apostol, Kent G.; and Dumroese, A. Kasten, "Transient physiological responses of planting frozen root plugs of Douglas-fir seedlings" (2008). USDA Forest Service / UNL Faculty Publications. 33.

https://digitalcommons.unl.edu/usdafsfacpub/33

This Article is brought to you for free and open access by the U.S. Department of Agriculture: Forest Service -National Agroforestry Center at DigitalCommons@University of Nebraska - Lincoln. It has been accepted for inclusion in USDA Forest Service / UNL Faculty Publications by an authorized administrator of DigitalCommons@University of Nebraska - Lincoln. 


\title{
Transient physiological responses of planting frozen root plugs of Douglas-fir seedlings
}

\author{
M. Anisul Islam, Douglass F. Jacobs, Kent G. Apostol, and R. Kasten Dumroese
}

\begin{abstract}
Short-term physiological responses of planting frozen (FR) and rapidly thawed (TR) root plugs of Douglas-fir (Pseudotsuga menziesii (Mirb.) Franco) seedlings were examined through time series $(0 \mathrm{~h}, 6 \mathrm{~h}, 12 \mathrm{~h}, 1$ day, 3 days, and 7 days) measurements in two separate experiments: $10{ }^{\circ} \mathrm{C}$ day : $6{ }^{\circ} \mathrm{C}$ night, $\mathrm{RH} 75 \%$ and $30{ }^{\circ} \mathrm{C}$ day : $20^{\circ} \mathrm{C}$ night, $\mathrm{RH} 50 \%$, respectively. Net photosynthesis, transpiration, shoot water potential, and root hydraulic conductance were lower in FR compared with TR seedlings under both growing conditions. Magnitude of difference in root hydraulic conductance was higher under warm-dry conditions. Chlorophyll fluorescence $\left(F_{\mathrm{v}} / F_{\mathrm{m}}\right)$ values were higher for TR than FR seedlings at 0 h, but similar thereafter for both growing conditions. Needle electrolyte leakage and chlorophyll content did not differ between FR and TR seedlings under both environmental regimes. Higher root $\mathrm{O}_{2}$ uptake was observed in FR seedlings in warm-dry conditions and in TR seedlings under cool-moist conditions. TR seedlings planted under warm-dry conditions had more flushed buds and new roots than FR seedlings, while no buds flushed for both FR and TR seedlings under coolmoist conditions. Comparatively higher photosynthesic rates in TR seedlings planted under warm-dry conditions likely contributed toward more new roots, which could be advantageous for survival and early growth.
\end{abstract}

Résumé : Les réactions physiologiques de deux traitements de motte radiculaire (gelée (FR) ou décongelée (TR)) sur les semis de douglas vert (Pseudotsuga menziesii (Mirb.) Franco) ont été étudiées en fonction du temps (0 h, 6 h, 12 h, 1 jour, 3 jours et 7 jours) et de deux conditions de croissances: froides et humides $\left(10{ }^{\circ} \mathrm{C}\right.$ jour : $6{ }^{\circ} \mathrm{C}$ nuit, taux d'humidité relative de $75 \%)$ ou chaudes et sèches $\left(30{ }^{\circ} \mathrm{C}\right.$ jour : $20^{\circ} \mathrm{C}$ nuit, taux d'humidité relative de $\left.50 \%\right)$. Les auteurs ont observé un taux de photosynthèse nette, un taux de transpiration, un potentiel hydrique des pousses et une conductance hydraulique des racines plus faibles avec les semis FR par rapport aux semis TR et ce pour les deux conditions de croissance. La différence de conductance hydraulique des racines était plus marquée dans les conditions de croissance chaudes et sèches. Les mesures de fluorescence de la chlorophylle $\left(F_{\mathrm{v}} / F_{\mathrm{m}}\right)$ étaient plus élevées pour les semis TR par rapport aux semis FR à $0 \mathrm{~h}$, ensuite les valeurs étaient similaires pour les deux conditions de croissance. La libération d'électrolytes des aiguilles et le contenu en chlorophylle n'ont pas été affectés par les traitements et les conditions de croissance. Le taux d'accumulation d'oxygène des racines était plus élevé pour les semis FR dans les conditions chaudes et sèches ainsi que pour les semis TR dans les conditions froides et humides. Les semis TR dans les conditions chaudes et sèches ont développé plus de bourgeons et de nouvelles racines par rapport aux semis FR. Dans les conditions de croissance froides et humides, aucun bourgeon ne s'est développé pour les deux traitements de mottes radiculaires. Le taux relatif plus élevé de photosynthèse des semis TR dans les conditions chaudes et sèches a possiblement contribué au développement de nouvelles racines, ce qui pourrait être avantageux pour la survie et la croissance à court terme des semis de douglas vert.

[Traduit par la Rédaction]

\section{Introduction}

In temperate climates, conifer seedling production often involves freezer storage of dormant seedlings at temperatures ranging from $-1{ }^{\circ} \mathrm{C}$ to $-5{ }^{\circ} \mathrm{C}$ prior to spring planting (McKay 1997; Paterson et al. 2001). Frozen storage reduces

Received 15 December 2005. Accepted 4 January 2008.

Published on the NRC Research Press Web site at cjfr.nrc.ca on 5 May 2008.

M.A. Islam, D.F. Jacobs, ${ }^{1}$ and K.G. Apostol. ${ }^{2}$ Hardwood Tree Improvement and Regeneration Center, Department of Forestry and Natural Resources, Purdue University, 715 West State Street, West Lafayette, IN 47907-2061, USA.

R.K. Dumroese. US Department of Agriculture Forest Service Southern Research Station, 1221 S. Main Street, Moscow, ID 83843, USA.

'Corresponding author (e-mail: djacobs@purdue.edu).

${ }^{2}$ Present address: Department of Biological Sciences, Bethel University, 3900 Rethel Drive, St. Panl, MN 55112, USA. problems associated with storage mold (Ritchie 2004) and provides flexibility in scheduling seedling delivery to planting sites in spring (Rose and Haase 1997). During frozen storage, root plugs usually freeze and attach to adjacent seedlings, requiring thawing prior to outplanting to facilitate seedling separation (Kooistra 2004). Additional nursery resources needed to completely thaw root plugs, along with potential negative impacts of thawing on seedling health and physiology (Hocking 1971; Puttonen 1986), suggests that direct planting of frozen root plugs after removal from storage would streamline the seedling production process and improve logistics of seedling delivery (Kooistra and Bakker 2002).

Several studies have reported that planting of frozen seedlings had no detrimental effects on seedling performance compared with thawed seedlings (Silim and Guy 1998; Kooistra and Bakker 2005). Camm et al. (1995) showed that thawing of frozen root plugs is unnecessary when seedlings are planted into warm soil (i.e., $18-32{ }^{\circ} \mathrm{C}$ ). However, there are reports suggesting higher mortality and reduced 
growth in frozen planted Norway spruce (Picea abies (L.) Karst.) seedlings compared with thawed seedlings (Helenius 2005).

Although some studies have focused on effects of thawing regime and long-term response of frozen-planted root plugs (Camm et al. 1995; Helenius 2005), little is known about the short-term physiological changes occurring in seedlings planted with frozen root plugs under relatively high or low ambient air temperatures. Spring planting of trees usually commences when average ambient temperature is around $10{ }^{\circ} \mathrm{C}$ and could continue at difficult to access sites until average ambient temperature rises to $30{ }^{\circ} \mathrm{C}$. These conditions are likely to occur under certain circumstances such as when snow limits access to high elevation sites until early summer. In two instances, one involving Engelmann spruce (Picea engelmannii Parry ex Engelm.) in Colorado, USA, and another with ponderosa pine (Pinus ponderosa Dougl. ex Laws.) and western white pine (Pinus monticola Dougl. ex D. Don) in Idaho, USA, seedlings outplanted with frozen plugs under hot, sunny weather exhibited near $100 \%$ mortality (D.F. Jacobs, unpublished data; R.K. Dumroese, unpublished data). Heikurinen (1981) reported similar plantation failure using frozen root plugs. It is possible that physiological dysfunctions may occur immediately, and be expressed in a short time interval after planting.

A long thaw time in the ground, which allows roots to resume normal physiological functioning, is unlikely to induce moisture stress in seedlings planted with frozen root plugs when air temperature is low (e.g., $<5{ }^{\circ} \mathrm{C}$ ), but might be deleterious when air temperature is high enough to cause an imbalance in root water uptake and shoot water loss. During late spring, summer, or early fall, when daytime air temperature and solar radiation are high, transpirational demand could result in moisture stress, which is possibly the dominant factor affecting performance and survival in newly planted seedlings (Burdett 1990; Grossnickle 2000). This upset in water balance could result in seedling desiccation and eventually mortality when transpirational demands of shoots are not met, which may be more deleterious in frozen-planted root plugs. For instance, high mortality rates observed in Norway spruce were partly associated with water stress caused by restricted water uptake in frozen root plugs (Helenius et al. 2004).

While planting frozen root plugs appears to be a promising technique for logistics of seedling delivery and planting operations, this new practice needs further investigation before being employed operationally. In the present study, we examined short-term (up to 7 days) responses of planting frozen and rapidly thawed Douglas-fir (Pseudotsuga menziesii (Mirb.) Franco) seedlings into two growing conditions $\left(10{ }^{\circ} \mathrm{C}\right.$ with $\mathrm{RH} 75 \%$ and $30{ }^{\circ} \mathrm{C}$ with $\mathrm{RH} 50 \%$ ) to better understand response mechanisms that take place immediately after transplanting. The daytime air temperatures $\left(10{ }^{\circ} \mathrm{C}\right.$ and $30{ }^{\circ} \mathrm{C}$ ) were selected, because spring planting often starts when ambient temperature is as low as $10{ }^{\circ} \mathrm{C}$, and $30{ }^{\circ} \mathrm{C}$ is the critical temperature where nursery stock in short-term storage is thought to be damaged (Emmingham et al. 2002).

We tested the hypothesis that planting seedlings while root plugs are frozen has detrimental impacts on seedling physiology compared with that of thawed root plugs. We measured chlorophyll fluorescence (CF), gas exchange, shoot water potential, root hydraulic conductance, root respiration, needle electrolyte leakage, and foliar chlorophyll content to identify physiological factors that may explain transplant failure, if any, associated with direct planting of frozen root plugs.

\section{Materials and methods}

\section{Plant material}

Douglas-fir seeds were collected from Flathead National Forest in western Montana (Hungry Horse Ranger District; $1675 \mathrm{~m})$ and were grown in $3 \mathrm{~cm} \times 15.2 \mathrm{~cm}(90 \mathrm{~mL})$ containers (315B Styroblock, Beaver Plastics, Ltd., Edmonton, Alberta) filled with $85 \%$ peat and $15 \%$ white fir (Abies concolor (Gord. \& Glend.) Lindl. Ex Hildebr.) sawdust at the University of Idaho nursery, Moscow, Idaho, $\left(46^{\circ} 44^{\prime} \mathrm{N}\right.$, $\left.117^{\circ} 00^{\prime} \mathrm{W}\right)$ for one season using standard operational methods. A total of 125 seedlings were placed in groups of 20, sealed in plastic bags, placed in cardboard boxes, and shipped to Purdue University in West Lafayette, Indiana, $\left(40^{\circ} 25^{\prime} \mathrm{N}, 86^{\circ} 55^{\prime} \mathrm{W}\right)$ in December 2006. Upon arrival at Purdue University, the root plug of each seedling was wrapped with Saran premium wrap (S.C. Johnson and Son, Racine, Washington), and the groups of 20 seedlings were placed into sealed plastic bags and stored in a freezer for 16 weeks at approximately $-2{ }^{\circ} \mathrm{C}$ until experiment initiation in April 2007. An additional plastic bag contained 5 seedlings that were subsequently destructively harvested to assess initial morphological characteristics.

\section{Root plug treatments, growing conditions, and experimental design}

An initial sample $(n=5)$ of seedlings had the following characteristics (mean \pm SD): height $(19.00 \pm 1.94 \mathrm{~cm})$, root collar diameter $(1.90 \pm 0.18 \mathrm{~mm})$, shoot $(0.66 \pm 0.03 \mathrm{~g})$ and root $(0.62 \pm 0.08 \mathrm{~g})$ dry mass. For frozen root $(\mathrm{FR})$ planting, seedlings remained in freezer storage until time of planting for both experiments. For thawed root (TR) planting, seedlings were taken out of the cooler and kept under dark conditions at room temperature for $24 \mathrm{~h}$, prior to experiment initiation. The media surrounding the root system were completely thawed after $24 \mathrm{~h}$ of thawing. The steps of thawing, transplanting, and moving of seedlings to the growth chamber were executed rapidly to avoid possible effects on seedling physiology external to root plug treatments. Seedlings were planted into Tree Pot -Tall One $(36 \mathrm{~cm} \times 10 \mathrm{~cm}$; $2.83 \mathrm{~L}$ ) pots (Treepots, Stuewe and Sons, Inc., Corvallis, Oregon) filled with 2:1 $(v / v)$ peat-vermiculite and immediately transferred to the growth chamber. At initiation of each experiment, pots were watered to near container capacity and subsequently rewatered when mass of pots indicated decline of soil moisture content to approximately $75 \%-80 \%$ of container capacity. For the first experiment, seedlings were transferred to a controlled environment chamber with temperatures of $10{ }^{\circ} \mathrm{C}$ day : $6{ }^{\circ} \mathrm{C}$ night, relative humidity of $75 \% \pm 2.5 \%$, an $18 \mathrm{~h}$ photoperiod with photosynthetic photon flux density, measured at seedling top height, of $300 \mu \mathrm{mol} \cdot \mathrm{m}^{-2} \cdot \mathrm{s}^{-1}$, provided by fluorescent lamps and incandescent bulbs. The diurnal vapor pressure deficit was calculated as $0.262 \mathrm{kPa}$. 
Two groups of root plug treatments (a total of 60 seedlings), FR and TR, were randomly distributed within the growth chamber. Pots were rearranged after the measurement period to avoid potential environmental variation within the growth chamber. Gas exchange, chlorophyll fluorescence, and shoot water potential measurements were recorded at $0 \mathrm{~h}, 6 \mathrm{~h}, 12 \mathrm{~h}, 1$ day, 3 days, and 7 days, while root hydraulic conductance, electrolyte leakage, chlorophyll content, and root respiration measurements were assessed only at 0 h, 1 day, 3 days, and 7 days. At each measurement time, measurements were taken on five randomly selected seedlings from each treatment (FR and TR). The experiment was a completely randomized design.

For the second experiment, the controlled environment chamber was set at temperatures of $30{ }^{\circ} \mathrm{C}$ day : $20{ }^{\circ} \mathrm{C}$ night, relative humidity of $50 \% \pm 2.5 \%$, an 18 h photoperiod with photosynthetic photon flux density, measured at seedling top height, of $300 \mu \mathrm{mol} \cdot \mathrm{m}^{-2} \mathrm{~s}^{-1}$, provided by fluorescent lamps and incandescent bulbs. The diurnal vapor pressure deficit was calculated as $2.275 \mathrm{kPa}$. All measurements were taken exactly as described for the first experiment.

\section{Chlorophyll fluorescence and gas exchange measurements}

Leaf photochemical efficiency was expressed as leaf chlorophyll fluorescence $\left(F_{\mathrm{v}} / F_{\mathrm{m}}\right)$. Chlorophyll fluorescence (CF) was measured on the upper $3 \mathrm{~cm}$ portion of the shoot using an integrated fluorescence chamber head, LI-6400-40 leaf chamber fluorometer (LI-COR, Inc., Lincoln, Nebraska) on five different seedlings from each treatment at $0 \mathrm{~h}, 6 \mathrm{~h}$, 12 h, 1 day, 3 days, and 7 days after planting.

The terminal shoots were allowed to dark adapt by covering the shoots with Ultra black and white Co-extruded LDPE Film (Hydrofarm, Inc., Petuluma, California) for 20 min before CF measurements. Briefly, needles were placed across the cuvette, and minimum fluorescence $\left(F_{\mathrm{o}}\right)$ was measured using a weak measurement beam $(<1 \mu \mathrm{mol}$ photons $\left.\cdot \mathrm{m}^{-2} \cdot \mathrm{s}^{-1}\right)$. Maximum fluorescence $\left(F_{\mathrm{m}}\right)$ was determined following a red light saturating pulse $(>7000 \mu \mathrm{mol}$ photons $\left.\cdot \mathrm{m}^{-2} \cdot \mathrm{s}^{-1}\right)$ and centered at wavelength of $630 \mathrm{~nm}$. The $F_{\mathrm{v}} / F_{\mathrm{m}}$ ratio $\left(\left[F_{\mathrm{m}}-F_{\mathrm{o}}\right] / F_{\mathrm{m}}\right)$, estimates maximal quantum yield of PS II photochemistry in dark-adapted needles.

Gas exchange (photosynthesis $(A)$, stomatal conductance $\left(g_{\mathrm{s}}\right)$, and transpiration $(E)$ ) measurements were performed after chlorophyll fluorescence measurements using a LI6400 portable photosynthesis system and 6400-05 conifer chamber (LI-COR, Inc.) on the same five different seedlings from each treatment at $0 \mathrm{~h}, 6 \mathrm{~h}, 12 \mathrm{~h}, 1$ day, 3 days, and 7 days after planting. Shoot water potential was determined using a pressure chamber (PMS Instruments, Inc., Corvallis, Oregon) immediately following the gas exchange measurements.

\section{Root hydraulic conductance}

Root hydraulic conductance $\left(K_{\mathrm{r}}\right)$ was measured in intact roots of the same seedlings used for gas exchange measurements with a high pressure flow meter (HPFM) (Dynamax Inc., Houston, Texas) as described by Tyree et al. (1995). The use of the HPFM allows for measurement of intact roots, because water is applied under increasing pressure through an excised stem (around root collar level) into the whole root system (Tyree et al. 1995). Stems of both frozen and thawed seedlings were cut $2 \mathrm{~cm}$ above the root collar, and flow rates of all seedlings were measured over a range of 0-2.75 $\mathrm{MPa}$ to obtain a linear pressure-flow relationship (Tyree et al. 1995). Root hydraulic conductance of each of five root systems was measured for each treatment on each measurement period and expressed as $\mathrm{kg} \cdot \mathrm{s}^{-1} \cdot \mathrm{MPa}^{-1}$.

\section{Needle electrolyte leakage}

Following measurement of root hydraulic conductance, needle electrolyte leakage (an indicator of cell integrity and cell membrane leakiness) was measured on the same seedlings with a SevenEasy Conductivity meter (Mettler Toledo, $\mathrm{GmbH}$, Switzerland) as described by Zwiazek and Blake (1990). Approximately $100 \mathrm{mg}$ (fresh mass) of needles were taken from five seedlings per treatment, washed with deionized water, and placed in separate vials, each containing $15 \mathrm{~mL}$ of deionized water. After incubation for $6 \mathrm{~h}$ on an orbital shaker, electrical conductivity of each solution (initial conductivity) was measured. Total electrolytes of the samples were obtained by autoclaving the samples at 120 ${ }^{\circ} \mathrm{C}$ for $20 \mathrm{~min}$. The autoclaved samples were allowed to cool, and total electrolytes of sample solutions were measured, and electrolyte leakage (EL) was calculated as initial conductivity as a percentage of total electrolytes.

\section{Chlorophyll content}

Needle chlorophyll was measured using the method of Arnon (1949) as modified to use dimethyl sulfoxide (DMSO) (Hiscox and Israelstam 1979). Dimethyl sulfoxide has been shown to be as reliable a solvent as acetone for chlorophyll extraction (Tait and Hik 2003), but does not require maceration. Needles (100 mg) were placed in test tubes with $7 \mathrm{~mL}$ of DMSO and transferred to an oven at 68 ${ }^{\circ} \mathrm{C}$ for $30 \mathrm{~min}$, with a marble on top of each tube to prevent solvent evaporation. The sample was then removed from the oven and made up to a total volume of $10 \mathrm{~mL}$ with DMSO. A $3 \mathrm{~mL}$ aliquot was transferred to a cuvette to measure absorbance. A Perkin-Elmer LC-95 UV/Visible spectrophotometer (Perkin-Elmer Inc., Norwalk, Connecticut) was used to measure solution absorbance at 645 and $663 \mathrm{~nm}$. Chlorophyll $a\left(\mathrm{C}_{a}\right)$, chlorophyll $b\left(\mathrm{C}_{b}\right)$, and total chlorophyll $\left(\mathrm{C}_{\mathrm{T}}\right)$ were determined from absorbance at $645 \mathrm{~nm}\left(D_{645}\right)$ and $663 \mathrm{~nm}\left(D_{663}\right)$ according to the following formulae (Arnon 1949):

$$
\begin{aligned}
& \mathrm{C}_{a}=0.0299 D_{645}-0.0046 D_{663} \\
& \mathrm{C}_{b}=0.0127 D_{663}-0.00269 D_{645} \\
& \mathrm{C}_{\mathrm{T}}=\mathrm{C}_{a}+\mathrm{C}_{b}
\end{aligned}
$$

\section{Root respiration}

Root respiration, which was measured as oxygen uptake using an oxygen electrode (model 58, Yellow Springs Instruments, Inc., Yellow Springs, Ohio), was determined at 1,3 , and 7 days after planting. The oxygen probe and the thoroughly cleaned root system were placed in a $1500 \mathrm{~cm}^{3}$ airtight cylinder filled with aerated distilled water that was continuously stirred with a magnetic stirrer. Root respiration measurements were made in respective growing temperatures and monitored for $20 \mathrm{~min}$ by recording oxygen uptake 
every 4 min. Root volume of each seedling was calculated by water displacement. Root respiration rates were calculated as a mean of oxygen uptake over time, and values were expressed in $\mathrm{mmol} \mathrm{O}_{2} \cdot \mathrm{cm}^{-3} \cdot \mathrm{min}^{-1}$.

\section{Statistical analysis}

Analysis of variance (ANOVA) was performed using SAS (SAS Institute Inc., Cary, North Carolina). Means were compared using Tukey's pairwise multiple comparisons test, and were considered significantly different at $P \leq 0.05$. In light of the relatively small sample size, retrospective power analysis of all parameters was performed. For the cool-moist experiment, the mean retrospective power $( \pm \mathrm{SE})$ for all analyses performed was $0.672 \pm 0.09$, while the mean retrospective power $( \pm \mathrm{SE})$ for only those analyses detecting significant differences was $0.958 \pm 0.04$. For the warm-dry experiment, the mean retrospective power $( \pm \mathrm{SE})$ for all analyses performed was $0.672 \pm 0.07$, while the mean retrospective power $( \pm \mathrm{SE})$ for only those analyses detecting significant differences was $0.930 \pm 0.04$. Gas exchange, $F_{\mathrm{v}} /$ $F_{\text {m }}$, root hydraulic conductance, shoot water potential, needle electrolyte leakage, chlorophyll content, and root respiration were analyzed for each measurement period. Data presented in figures are means of five replicates; each individual seedling constituted a replicate.

\section{Results}

\section{Cool-moist environment experiment}

At experiment initiation $(0 \mathrm{~h}), F_{\mathrm{v}} / F_{\mathrm{m}}$ values for seedlings planted with frozen root plugs (FR) compared with thawed root plugs (TR) were 0.69 and 0.72 , respectively, but were not significantly different (Fig. 1A). $F_{\mathrm{v}} / F_{\mathrm{m}}$ values for both FR and TR seedlings varied from 0.60 to 0.73 for the experiment duration. Although $F_{\mathrm{v}} / F_{\mathrm{m}}$ values were higher for FR than TR seedlings at day 3, they were not significantly different.

There were significant treatment, time, and treatment $\times$ time interaction effects on photosynthesis $(A)$ (Table 1). Negative mean values for $A$ (i.e., respiration in excess of photosynthesis) were recorded in FR seedlings at $0 \mathrm{~h}$, but $A$ continued to increase as the experiment progressed (Fig. 2A). Although TR seedlings exhibited significantly higher $A$ than FR seedlings over the first $24 \mathrm{~h}$, rates declined on day 3 but increased on day 7 (Fig. 2A). There were significant effects for treatment and time on stomatal conductance $\left(g_{\mathrm{s}}\right)$, but the treatment $\times$ time interaction was not significant (Table 1). Thawed planted seedlings maintained higher $g_{\mathrm{s}}$ during the measurement period compared with frozen planted seedlings (Fig. 2B). A similar trend in transpiration $(E)$ was observed for both FR and TR seedlings (Fig. 2C).

Root treatments had significant $(P=0.0178)$ effects on shoot water potential $\left(\psi_{\mathrm{w}}\right)$ (Table 1$)$. Thawed planted seedling had a significantly higher $\psi_{\mathrm{w}}$ compared with frozen planted seedlings at $12 \mathrm{~h}$ and maintained higher $\psi_{\mathrm{w}}$ thereafter (Fig. 1B). Although TR seedlings showed slightly higher rates of root hydraulic conductance than FR seedlings, they were not significantly different (Table 1; Fig. 1C). There were no significant differences in needle electrolyte leakage, root respiration rates, and chlorophyll content between FR and TR seedlings (Table 1).

No terminal or lateral buds began to elongate either in FR and TR seedlings during the duration of the experiment.

\section{Warm-dry environment experiment}

Response of maximal quantum yield of PS II photochemistry in dark-adapted FR and TR Douglas-fir seedlings is shown in Fig. 1D. At experiment initiation $(0 \mathrm{~h}), F_{\mathrm{v}} / F_{\mathrm{m}}$ values differed significantly between FR (0.64) and TR (0.74) seedlings. Thereafter, $F_{\mathrm{v}} / F_{\mathrm{m}}$ ranged from 0.72 to 0.75 in both TR and FR seedlings. Although $F_{\mathrm{v}} / F_{\mathrm{m}}$ was higher for TR than FR seedlings at $12 \mathrm{~h}$ and 7 days, differences were not statistically significant.

There were significant treatment, time, and treatment $\times$ time interaction effects on $A$ (Table 1). Thawed seedlings maintained significantly $(P=0.0002)$ higher $A$ than frozen planted seedlings up to $12 \mathrm{~h}$ (Fig. 2D). Frozen planted seedlings exhibited a very low mean value for $A(0.110 \mu \mathrm{mol}$ $\left.\mathrm{CO}_{2} \cdot \mathrm{m}^{-2}{ }^{2} \mathrm{~s}^{-1}\right)$ at $0 \mathrm{~h}$, while thawed seedlings had significantly higher $A\left(3.049 \mu \mathrm{mol} \mathrm{CO} \cdot \mathrm{m}^{-2} \cdot \mathrm{s}^{-1}\right)$. Photosynthesis increased gradually for FR seedlings from $0 \mathrm{~h}$ to 3 days, but declined by day 7 . Thawed seedlings had significantly higher $A$ than frozen planted seedlings at $12 \mathrm{~h}$, but overall rates fluctuated throughout the measurement period. Both $g_{\mathrm{s}}$ and $E$ measurements showed the same overall trend. Rates of $g_{\text {s }}$ and $E$ were higher in TR compared with FR seedlings except for day 1 (Figs. 2E and 2F). Values for $g_{\text {s }}$ and $E$ were significantly lower in FR compared with TR seedlings at $0 \mathrm{~h}$ (Figs. 2E and 2F). Thawed seedlings maintained higher $g_{\mathrm{s}}$ and $E$ on day 7 compared with frozen planted seedlings, but differences were not significant.

Root treatments had significant $(P=0.0005)$ effects on $\psi_{\mathrm{w}}$. Thawed planted seedlings had significantly less negative $\psi_{\mathrm{w}}$ compared with frozen planted seedlings at $0 \mathrm{~h}$ and day 1 . Time zero $\psi_{\mathrm{w}}$ values were $-1.34 \pm 0.10 \mathrm{MPa}$ and $-1.03 \pm$ $0.04 \mathrm{MPa}$ for FR and TR, respectively (Fig. 1E). The FR seedlings had more negative $\psi_{\mathrm{w}}$ over the measurement period compared with TR seedlings (Table 1). Frozen planted seedlings had a gradual increase in $\psi_{\mathrm{w}}$ on days 3 and 7 . Overall, root hydraulic conductance was also significantly higher $(P=0.0206)$ in TR compared with FR seedlings (Fig. 1F). Needle electrolyte leakage (EL) was significantly higher on day 3 in FR compared with TR seedlings, though EL was not significantly different at any other measurement date.

One day after planting, root respiration rates were $25 \%$ higher in FR $\left(2.15 \mathrm{mmol} \mathrm{O}_{2} \cdot \mathrm{cm}^{-3} \cdot \mathrm{min}^{-1}\right)$ compared with TR seedlings $\left(1.61 \mathrm{mmol} \mathrm{O}{ }_{2} \cdot \mathrm{cm}^{-3} \cdot \mathrm{min}^{-1}\right)$. However, root respiration remained similar between $\mathrm{FR}$ and TR seedlings on days 3 and 7 .

Thawed planted seedlings had a significantly higher number of new (white, unsuberized) roots on day 7 (38.2 \pm 4.97$)$ compared with frozen planted seedlings (20.4 \pm 4.62). Although TR seedlings had a higher mean number of flushed terminal and lateral buds $(3.6 \pm 0.22)$ than FR seedlings $(0.4 \pm 0.24)$ at day 7 , differences were not significant.

\section{Discussion}

Chlorophyll fluorescence is related to activity of chloro- 
Fig. 1. (A) Chlorophyll fluorescence, (B) shoot water potential, and (C) root hydraulic conductance of frozen (FR) and thawed root plugs (TR) of Douglas-fir planted at $10{ }^{\circ} \mathrm{C}$ day : $6{ }^{\circ} \mathrm{C}$ night, RH $75 \%$, vapor pressure deficit (VPD) $=0.262 \mathrm{kPa}$ and (D) chlorophyll fluorescence, (E) shoot water potential, and (F) root hydraulic conductance of FR and TR of Douglas-fir planted at $30{ }^{\circ} \mathrm{C}$ day : $20{ }^{\circ} \mathrm{C}$ night, RH $50 \%$, $\mathrm{VPD}=2.275 \mathrm{kPa}$. Each data point indicates mean $\pm \mathrm{SE}(n=5)$.
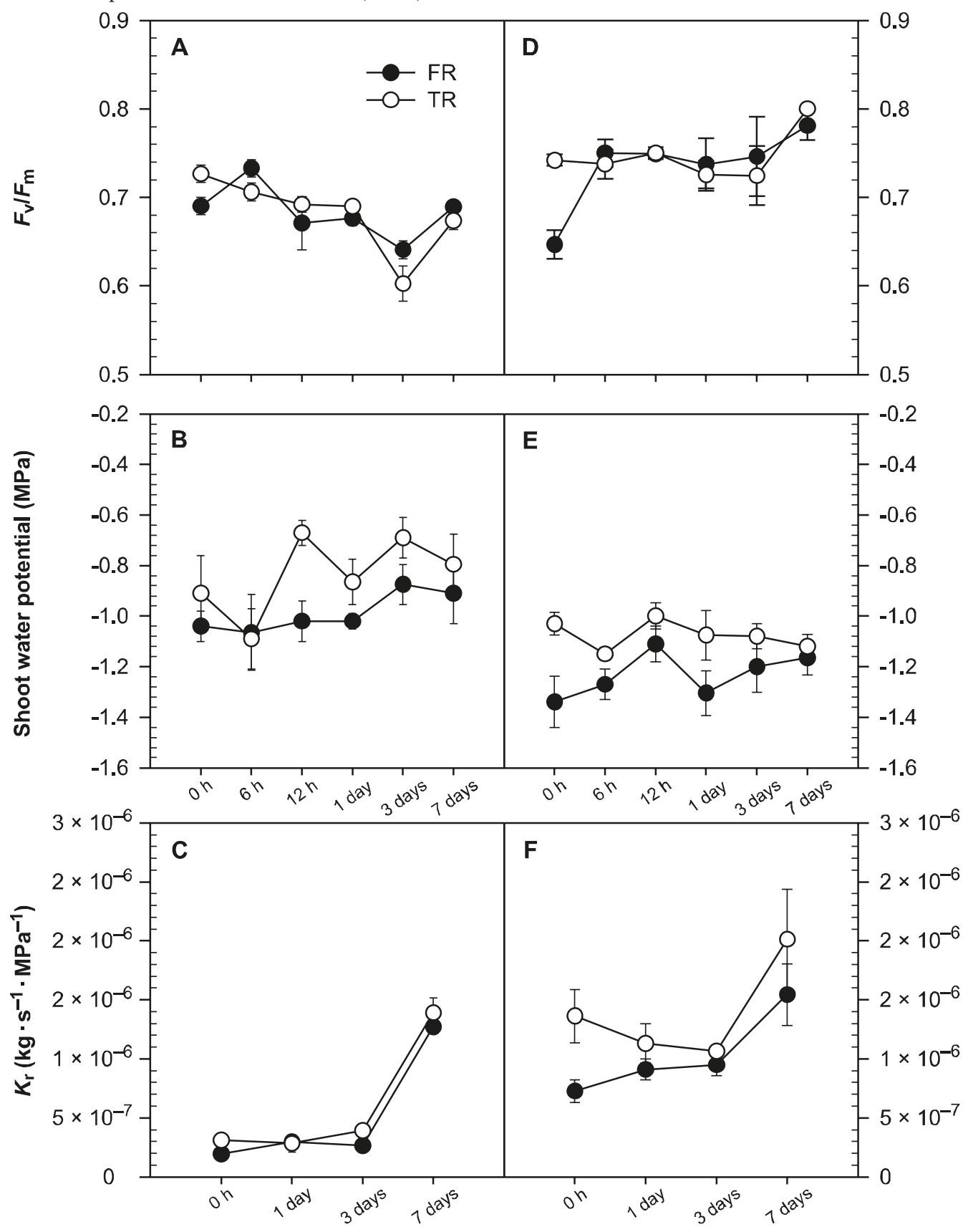

Time after planting

phyll in photosynthetic reaction centers, and thus can be used to measure photosynthetic efficiency (Genty et al. 1989). $F_{\mathrm{v}} / F_{\mathrm{m}}$ reflects potential quantum efficiency of PSII and, therefore, provides a sensitive indicator of plant photosynthetic performance (Björkman and Demmig 1987) and plant stress. A healthy seedling is reported to have $F_{\mathrm{v}} / F_{\mathrm{m}}$ close to 0.80 , and a decrease from this value indicates stress (Fracheboud et al. 1999). Frozen root plugs showed an increase in $F_{\mathrm{v}} / F_{\mathrm{m}} 6 \mathrm{~h}$ after planting under both environmental regimes (Figs. $1 \mathrm{~A}$ and $1 \mathrm{D}$ ). The increase in $F_{\mathrm{v}} / F_{\mathrm{m}}$ in FR shortly after planting may suggest higher metabolic activity. In Scots pine (Pinus sylvestris L.), when $F_{\mathrm{v}} / F_{\mathrm{m}}$ fell below 0.40 , no recovery occurred, even though soil water became available as a result of soil thawing (Repo et al. 2005). Similarly, Gillies and Binder (1997) observed needle damage in white spruce (Picea glauca (Moench) Voss) seedlings subjected to cold stress when $F_{\mathrm{v}} / F_{\mathrm{m}}$ was $<0.50$. In the present study, we observed no significant needle damage and higher $(>0.50) F_{\mathrm{v}} / F_{\mathrm{m}}$ values for both FR and TR seedlings even at $0 \mathrm{~h}$. 


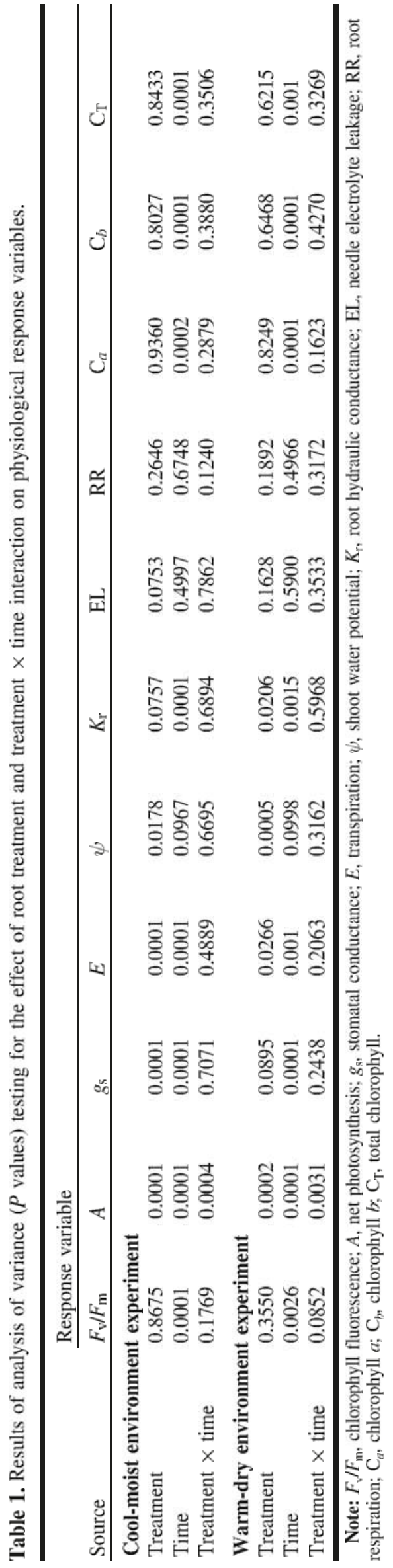

Roots must efficiently absorb and transport water from soil to meet shoot transpirational demands. Planting frozen root plugs may result in transplanting stress associated with an initially greater resistance to root water uptake. In both experiments, $\psi_{\mathrm{w}}$ in TR seedlings was significantly higher than that of FR seedlings under cool-moist and warm-dry conditions (Figs. 1B and 1E). However, treatment differences in $\psi_{\mathrm{w}}$ under cool-moist conditions became prominent at $12 \mathrm{~h}$, while the difference diminished after $12 \mathrm{~h}$ under warm-dry conditions. While $\psi_{\mathrm{w}}$ in FR under cool-moist conditions remained low for the first $24 \mathrm{~h}$ after planting, it gradually increased after $6 \mathrm{~h}$ under warm-dry conditions, suggesting thawing of frozen planted roots and gradual resumption of root water movement. This water deficit condition in FR was possibly due to frozen portions of tap root, which inhibited water flow from unfrozen lateral roots for the first $24 \mathrm{~h}$ compared with TR. This is reflected by relatively low root hydraulic conductance $\left(K_{\mathrm{r}}\right)$ in FR compared with TR in both growing environments (Figs. 1C and 1F). Both FR and TR exhibited very little $K_{\mathrm{r}}$ until day 3 (Fig. 1C). Although $K_{\mathrm{r}}$ increased significantly thereafter, the magnitude was still lower than that of FR and TR in 3 days under warm-dry conditions (Fig. 1F). Limited access to water may have induced restriction of root water flow that consequently resulted in lower shoot hydration observed in FR, which is similar to low soil temperature effects reported in Engelmann spruce (Kaufmann 1975). Because root plugs of FR were still frozen at $0 \mathrm{~h}$ under cool-moist conditions, the lower $\psi_{\mathrm{w}}$ observed in FR compared with TR (Figs. 1B and $1 \mathrm{E}$ ) could be related to a reduction in root water uptake resulting in decreased $g_{\mathrm{s}}$ and $E$ (Figs. 2B, 2E, 2C, and 2F) and, in turn, causing much lower $A$ (Figs. 2A and 2D) than in TR. Rates of $A$ and $g_{\mathrm{s}}$ for FR seedlings remained lower than for TR seedlings until day 3 under cool-moist conditions and until day 1 under warm-dry conditions. Treatment differences diminished thereafter, suggesting differing rates at which seedlings resume physiological functioning and photosynthetic activity when planted under different environmental regimes. Previous studies revealed that both $g_{\text {s }}$ and root water uptake were reduced when plants were exposed to differing environmental stresses (Wan et al. 1999; Kamaluddin and Zwiazek 2001), suggesting that root water flow and overall plant water status are interrelated. In our present study, it is plausible that initial lower rates of $E$ and $g_{\mathrm{s}}$ in FR seedlings were partly due to reduction in $K_{\mathrm{r}}$ (Figs. 2C and 2F).

When water demand increases, severity of stress becomes detrimental when thawing is delayed. Once root plugs thaw and seedlings acclimate to growing conditions, however, seedlings become functional and resume growth. Camm et al. (1995) observed more new root development in slowly thawed seedlings 5 and 8 days after transplanting compared with frozen planted seedlings of interior spruce (Picea glauca (Moench) Voss $\times$ Picea engelmannii Parry ex Engelm.). However, at day 15 there was no significant difference in root development for either stock type. Minor differences in physiological responses between frozen and thawed root plugs observed by Camm et al. (1995) and Kooistra and Bakker (2002) may have been associated with planting into favorable environmental conditions, allowing frozen root plugs to thaw and resume normal physiological 
Fig. 2. (A) Photosynthesis, (B) stomatal conductance, and (C) transpiration of frozen (FR) and thawed root plugs (TR) of Douglas-fir planted at $10{ }^{\circ} \mathrm{C}$ day : $6{ }^{\circ} \mathrm{C}$ night, $\mathrm{RH} 75 \%$, vapor pressure deficit (VPD) $=0.262 \mathrm{kPa}$ and (D) photosynthesis, (E) stomatal conductance, and (F) transpiration of FR and TR of Douglas-fir planted at $30{ }^{\circ} \mathrm{C}$ day : $20{ }^{\circ} \mathrm{C}$ night, RH $50 \%$, VPD $=2.275 \mathrm{kPa}$. Each data point indicates mean $\pm \operatorname{SE}(n=5)$.
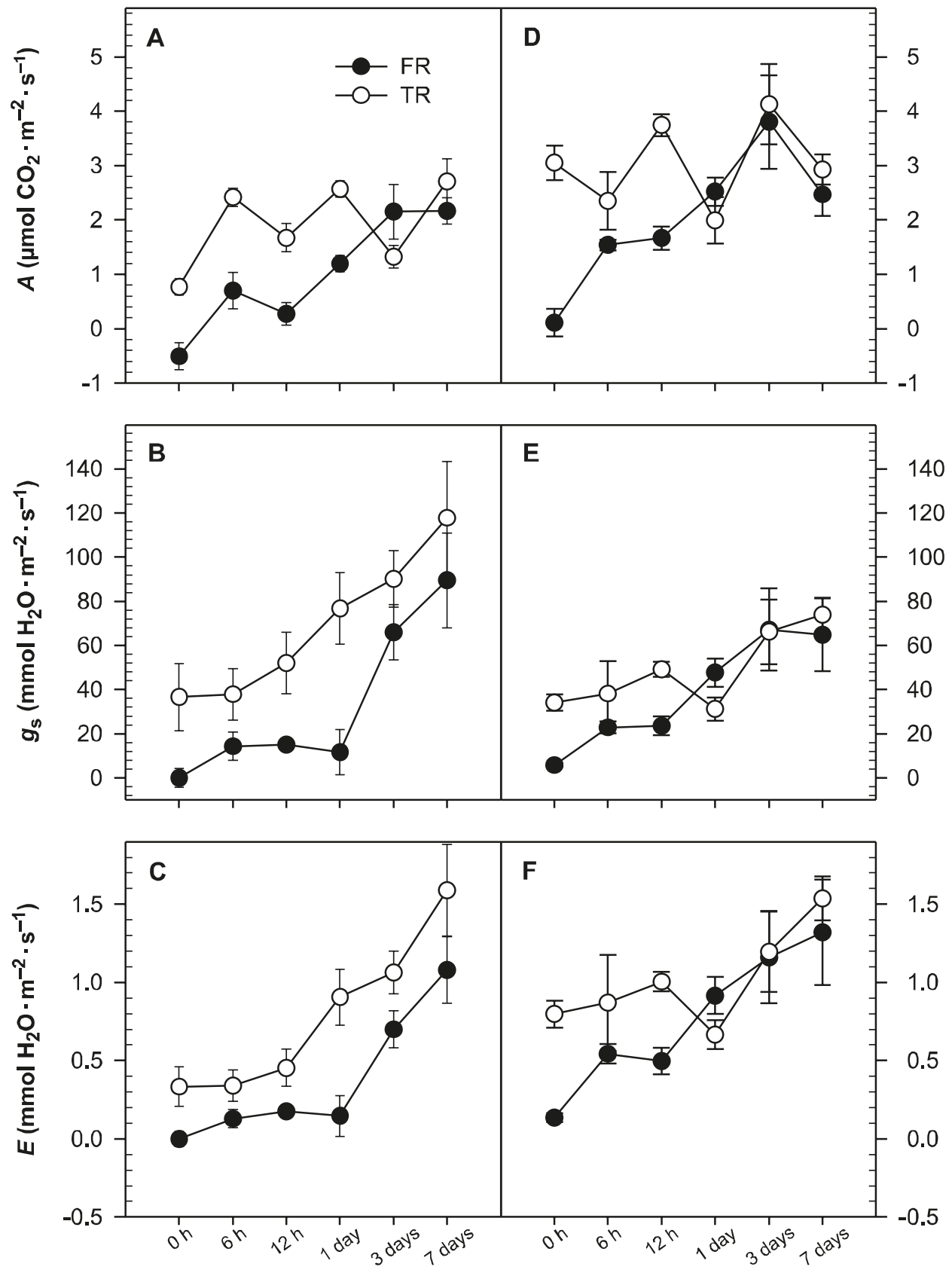

Time after planting

functions. Kooistra and Bakker (2002) reported maximum air temperatures of $31{ }^{\circ} \mathrm{C}$ in May and $24{ }^{\circ} \mathrm{C}$ in June (mean for a 2 days planting interval in each month). Air temperatures reported at time of planting were $14-17{ }^{\circ} \mathrm{C}$ in Camm et al. (1995). In addition, vapor pressure deficit present at time of planting in Camm et al. (1995) was very low (Grossnickle 2000), which may have further alleviated potential imbalance between root water uptake and shoot water loss. This may help explain disappearance in physiological differences between seedlings planted with root plugs thawed and frozen when growth and physiological responses are assessed several days or one growing season after planting (Camm et al. 1995; Kooistra and Bakker 2002).

Although no significant new root growth was observed in either FR or TR seedlings under cool-moist conditions, TR seedlings grown under warm-dry conditions had significantly more new roots than FR seedlings. Thawed seedlings had a greater mean number of flushed buds compared with frozen planted seedlings under warm-dry conditions. Higher $A$ likely contributed toward emergence of more new roots in 
TR seedlings, as proliferation of new roots in Douglas-fir seedlings is largely dependent upon current photosynthesis (van den Driessche 1987; Philipson 1988). This finding implicates an advantage in establishment success of TR compared with FR seedlings, as rapid new root growth is critical toward overcoming planting stress (Grossnickle 2005).

In the present study, we cannot precisely identify immediate root physiological responses following transplant into either environmental regime. Disruption of root plasma membrane functions could be a factor that would interfere with water uptake, and consequently a number of plant processes (Crane and Möller 1988). Apostol and Zwiazek (2003) have shown that an increase of tissue ion leakage indicates loss of membrane integrity and leads to failure in root functions. Comparatively higher root respiration rates in FR compared with TR seedlings, as an initial transient response, might reflect increased respiratory substrates from damaged cells, which is commonly observed as a wounding response (Klotz et al. 2003). Higher oxygen uptake by thawed roots planted under cool-moist environment could be due to resumption of metabolic and cell repair processes. It is possible that FR seedlings planted under cool-moist conditions had not initiated the same processes, as soil temperature was not very conducive for higher oxygen uptake. We hypothesize that a similar mechanism affecting survival in FR is partly due to membrane permeability, resulting in increased membrane electrolyte leakage. This requires further investigation.

\section{Conclusions}

Results from previous reports combined with our current observations suggest that field establishment success of frozen root plugs is dictated by environmental conditions to which they are exposed at the time of planting. Under hot, sunny conditions with high vapor pressure deficit, delay in thawing could lead to an imbalance between root water uptake and transpiration that may result in seedling desiccation and, if sustained, mortality. Thus, on planting dates where atmospheric evaporative demand is high, it may be advisable to avoid planting frozen root plugs. Conversely, potential for FR seedlings to establish and survive is high when planting is conducted under cloudy skies with high humidity, cooler temperatures, and low vapor pressure deficit. This has been observed in western larch (Larix occidentalis Nutt), lodgepole pine (Pinus contorta Dougl. ex Loud. var. latifolia Engelm. ex S. Wats), and interior spruce seedlings planted while root plugs were frozen (Kooistra and Bakker 2005).

Our data show that the rate of resumption in physiological processes such as gas exchange and water movement is dependent on the outplanting environment; thawing of root plugs accelerated the resumption processes. Initial significant differences between TR and FR in physiological activity diminished slowly (1-3 days) when planted under coolmoist conditions and rapidly ( $12 \mathrm{~h}-1$ day) under warm-dry conditions. Subsequently $A, E, g_{\mathrm{s}}, \psi_{\mathrm{w}}$, and root hydraulic conductance for both TR and FR seedlings converged by day 7 after planting. Although no lasting negative effects were observed over the study period, we conclude that higher initial rates of photosynthesis and water conductance in thawed seedlings planted under both cool-moist and warm-dry conditions may be beneficial toward alleviating initial outplanting stress.

\section{Acknowledgements}

We gratefully acknowledge funding from the USDA Forest Service, the Hardwood Tree Improvement and Regeneration Center at Purdue University, and the Department of Forestry and Natural Resources, Purdue University to support this research. We thank N. King, M. Nicodemus, J. Sloan, and M. Williams for technical assistance.

\section{References}

Apostol, K.G., and Zwiazek, J.J. 2003. Hypoxia affects root sodium and chloride concentrations and alters water conductance in salttreated jack pine (Pinus banksiana) seedlings. Trees (Berl.), 17: 251-257.

Arnon, D.I. 1949. Copper enzymes in isolated chloroplasts. Polyphenoloxidasses in Beta vulgaris. Plant Physiol. 24: 1-15. PMID:16654194.

Björkman, O., and Demmig, B. 1987. Photon yield of $\mathrm{O}_{2}$ evolution and chlorophyll fluorescence characteristics at $77 \mathrm{~K}$ among vascular plants of diverse origins. Planta, 170: 489-504. doi:10. 1007/BF00402983.

Burdett, A.N. 1990. Physiological processes in plantation establishment and the development of specifications for forest planting stock. Can. J. For. Res. 20: 415-427.

Camm, E.L., Guy, R.D., Kubien, D.S., Goetze, D.C., Silim, S.N., and Burton, P.J. 1995. Physiological recovery of freezer-stored white and Engelmann spruce seedlings planted following different thawing regimes. New For. 10: 55-77.

Crane, F.I., and Möller, I.M. 1988. Plasmalemma redox functions in plants. Physiol. Plant. 73: 159-160.

Emmingham, W.H., Cleary, B.D., and DeYoe, D.R. 2002. Seedling care and handling. The woodland workbook. Prepared by the Oregon State University Extension Service. EC 1095.

Fracheboud, Y., Haldimann, P., Leipner, J., and Stamp, P. 1999. Chlorophyll fluorescence as a selection tool for cold tolerance of photosynthesis in maize (Zea mays L.). J. Exp. Bot. 50: 1533-1540. doi:10.1093/jexbot/50.338.1533.

Genty, B., Briantais, J., and Baker, N. 1989. The relationship between the quantum yield of photosynthetic electron transport and quenching of chlorophyll fluorescence. Biochim. Biophys. Acta, 990: 87-92.

Gillies, S.L., and Binder, W.D. 1997. The effect of sub-zero temperatures in the light and dark on cold-hardened, dehardened and newly flushed white spuce (Picea glauca (Moench.) Voss) seedlings. New For. 13: 91-104.

Grossnickle, S.C. 2000. Ecophysiology of northern spruce species: The performance of planted seedlings. NRC Research Press, Ottawa, Ont.

Grossnickle, S.C. 2005. Importance of root growth in overcoming planting stress. New For. 30: 275-294.

Heikurinen, J.K.K. 1981. Current management practices in boreal mixed-wood forest. In Proceedings of the Boreal Mixed-Wood Symposium. Can. For. Serv. Gt. Lakes For.. Cent. Inf. Rep. OP-9. pp. 184-192.

Helenius, P. 2005. Effect of thawing regime on growth and mortality of frozen-stored Norway spruce container seedlings planted in cold and warm soil. New For. 29: 33-41.

Helenius, P., Luoranen, J., and Rikala, R. 2004. Effect of thawing duration and temperature on field performance of frozen-stored Norway spruce container seedlings. Silva Fenn. 38: 347-352. 
Hiscox, J.D., and Israelstam, G.F. 1979. Method for the extraction of chlorophyll from leaf tissue without maceration. Can. J. Bot. 57: 1332-1334. doi:10.1139/b79-163.

Hocking, D. 1971. Effect and characteristics of pathogens on foliage and buds of cold stored white spruce and lodgepole pine seedlings. Can. J. For. Res. 1: 208-215. doi:10.1139/x71-028.

Kamaluddin, M., and Zwiazek, J.J. 2001. Metabolic inhibition of root water flow in red-osier dogwood (Cornus stolonifera) seedlings. J. Exp. Bot. 52: 739-745. PMID:11413210.

Kaufmann, M.R. 1975. Leaf water stress in Engelmann spruce; influence of the root and shoot environments. Plant Physiol. 58: 841-844.

Klotz, K.L., Finger, F.F., and Anderson, M.D. 2003. Induction of respiration by wounding is temperature dependent in sugarbeet (Beta vulgaris L.) root. American Society of Plant Biologists Annual Meeting. P. 81. Abstract No. 283.

Kooistra, C.M. 2004. Seedling storage and handling in western Canada. In National Proceedings: Forest and Conservation Nursery Associations. Coordinated by L.E. Riley, R.K. Dumroese, and T.D. Landis. Proc. RMRS-P-33. US Department of Agriculture, Forest Service, Rocky Mountain Research Station, Fort Collins, Co. pp. 15-21.

Kooistra, C.M., and Bakker, J.D. 2002. Planting frozen conifer seedlings: Warming trends and effects on seedling performance. New For. 23: 225-237.

Kooistra, C.M., and Bakker, J.D. 2005. Frozen-stored conifer container stock can be outplanted without thawing. Native Plants, J. 6: 267-278. doi:10.2979/NPJ.2005.6.3.267.

McKay, H.M. 1997. A review of the effect of stresses between lifting and planting on nursery stock quality and performance. New For. 13: 369-399.

Paterson, J., DeYoe, D., Millson, S., and Galloway, R. 2001. Handling and planting of seedlings. In Regenerating the Canadian Forest: principles and practices for Ontario. Edited by R.G. Wagner and S. Colombo. Fitzhenry and Whiteside Limited, Markham, Ont. pp. 325-341.

Philipson, J.J. 1988. Root growth in Sitka spruce and Douglas-fir transplants: dependence on the shoot and stored carbohydrates. Tree Physiol. 4: 101-108. PMID:14972820.
Puttonen, P. 1986. Carbohydrate reserves in Pinus sylvestris seedlings needles as an attribute of seedling vigor. Scand. J. For. Res. 1: 181-193.

Repo, T., Kalliokoski, T., Domish, T., Lehto, T., Mannerkoski, H., Sutinen, S., and Finér, L. 2005. Effects of timing of soil frost thawing on Scots pine. Tree Physiol. 25: 1053-1062. PMID:15929936.

Ritchie, G.A. 2004. Container seedling storage and handling in the Pacific Northwest: Answers to some frequently asked questions. Coordinated by L.E. Riley, R.K. Dumroese, and T.D. Landis. Proc. RMRS-P-33. US Department of Agriculture, Forest Service, Rocky Mountain Research Station, Fort Collins, Co. pp. 3-7.

Rose, R., and Haase, D. 1997. Thawing regimes for freezer-stored container stock. Tree Planters' Notes, 48: 12-18.

Silim, S.N., and Guy, R.D. 1998. Influence of thawing duration on performance of conifer seedlings. In Proceedings of the 1995, 1996, and 1997 Annual Meetings of the Forest Nursery Association of British Columbia, Canada. Edited by C.M. Kooistra. Forest Nursery Association of B.C., Vernon, B.C. pp. 155-162.

Tait, M.A., and Hik, D.S. 2003. Is dimethyl sulfoxide a reliable solvent for extracting chlorophyll under field conditions? Photosynth. Res. 78: 87-91. doi:10.1023/A:1026045624155. PMID:16245067.

Tyree, M.T., Patino, S., Bennink, J., and Alexander, J. 1995. Dynamic measurements of root hydraulic conductance using a high pressure flow meter in the laboratory and field. J. Exp. Bot. 46: 83-94. doi:10.1093/jxb/46.1.83.

van den Driessche, R. 1987. Importance of current photosynthesis to new root growth in planted conifer seedlings. Can. J. For. Res. 17: 776-782.

Wan, X., Landhausser, S.M., Zwiazek, J.J., and Lieffers, V.J. 1999. Root water flow and growth of aspen (Populus tremuloides) at low root temperatures. Can. J. For. Res. 29: 332-338. doi:10. 1139/cjfr-29-3-332.

Zwiazek, J.J., and Blake, T.J. 1990. Effects of preconditioning on electrolyte leakage and lipid composition in black spruce (Picea mariana) stressed with polyethylene glycol. Physiol. Plant. 79: 71-77. doi:10.1111/j.1399-3054.1990.tb05868.x. 